\title{
Administrasi Layanan Khusus
}

\author{
Yuni Kartika Sari \\ Universitas Negeri Padang \\ Indonesia \\ E-mail : yunikartikasari446@gmail.com
}

\begin{abstract}
Abstrak-This article describes the Special Services Administration which is part of the Education administration. Special service administration consists of: (1) Library. (2) UKS, (3) Canteen, (4) Transportation, (5) Labor (6)Worship Facilities, (7) Cooperatives, (8) Dormitory, purpose of special service administration to facilitate all activities in schools and meet student needs so that learning objectives can be achieved effectively and efficiently.The special service management functions include: (1) planning, in the form of needs analysis and preparation of special service programs; (2) organizing, in the form of division of tasks to carry out special service programs; (3) mobilization, in the form of regulation in the implementation of special services, and (4) supervision, in the form of program monitoring and performance evaluation of special service programs in schools. So that special services need to be managed with an effective management process in order to strengthen the education management process, especially at the school level. Special services are held in schools with the aim of facilitating the implementation of teaching in order to achieve the goals of education in schools.
\end{abstract}

Keywords-(Administrasi Layanan Khusus)

\section{PENDAhUluan}

Proses belajar mengajar memerlukan dukungan fasilitas yag tidak secara langsung dipergunakan di kelas. Fasilitas yang tidak secara langsung antara lain adalah perpustakaan sekolah, koperasi sekolah, usaha kesehatan sekolah dan kafetaria sekolah.

Administrasi layanan khusus adalah memberi layanan secara khusus atau suatu usaha yang tidak secara langsung berkenaan dengan proses belajar mengajar di kelas. Tetapi secara khusus diberikan oleh sekolah kepada para siswamnya agar mereka lebih optimal dalam melaksanakan proses belajar. Ada berbagai jenis layanan khusus, tetapi hanya empat jenis yang akan dibicarakan dalam kesempatan ini. Keempat jenis administrasi layanan husus itu adalah perpustakaan sekolah, koperasi sekolah, usaha kesehatan sekolah dan kafetaria sekolah.

Menurut Kusmintardjo, sekolah tidak akan berfungsi jika tidak ada sesuatu yang membuatnya berfungsi. Dalam sebuah pendidikan harus mempunyai unsur-unsur yang meliputi administrasi sekolah. Unsur-unsur dalam administrasi sekolah tersebut masing-masing mempunyai fungsi, hubungan, dan ketergantungan dengan komponen-komponen lainnya. Unsur-unsur tersebut meliputi: (a) administrasi murid, (b) administrasi kurikulum, (c) administrasi personil, (d) administrasi materiil, (e) administrasi keuangan, (f) administrasi hubungan sekolah dan masyarakat, dan (g) administrasi pelayanan khusus. Tidak hanya keenam fungsi administrasi yang mendominasi terbentuknya kondisi pembelajaran yang nyaman, dengan menambah layanan khusus di sekolah peserta didik atau murid akan dapat melengkapi usaha pencapaian tujuan pendidikan di sekolah.

Hingga saat ini layanan khusus di anggap sangat penting dalam perwujudan pendidikan. Maka hampir setiap sekolah di Indonesia menyediakan layanan khusus bagi peserta didik. Memang perlu adanya usaha pemerintah untuk terus mendukung teraplikasinya layanan khusus bagi peserta didik ini agar peserta didik merasa nyaman, senang dan betah di lingkungan sekolah. Manajemen layanan khusus di sekolah ditetapkan dan diorganisasikan untuk memudahkan atau memperlancar pembelajaran, serta dapat memenuhi kebutuhan khusus siswa di sekolah.

Kusmintardjo (1992:4), pelayanan khusus atau pelayanan bantuan diselenggarakan di sekolah dengan maksud untuk memperlancar pelaksanaan pengajaran dalam rangka pencapaian tujuan pendidikan di sekolah. Kepala sekolah perlu mempertimbangkan secara matang apabila akan menyelenggarakan program layanan khusus. Kepala sekolah harus selalu melihat hubungan antara layanan khusus dengan program pendidikan secara menyeluruh. Pada hakekatnya, untuk mempermudah penyelenggaraan kegiatan layanan khusus, kepala sekolah dituntut memiliki kemampuan menerapkan pendekatan psikologis didalam pengadministrasian personal

Disamping pendekatan psikologis dalam mengadministrasi personal, ada pendekatan lain yang dapat dipergunakan oleh kepala sekolah, yakni pendekatan analisis bidang. Dalam pendekatan ini, kepala sekolah harus mengetahui tanggung jawab dari masing-masing personal yang terlibat.

Oleh karena itu, sebagai profesional yang akan terjun dalam dunia pendidikan khususnya di lingkungan sekolah, kita wajib mengetahui dan memahami layanan khusus apa yang terdapat di sekolah. Tujuan yang diinginkan tidak lain dan tidak bukan untuk menciptakan kondisi dan situasi pembelajaran yang nyaman dan menyenangkan bagi peserta didik. Dengan proses pembelajaran yang baik, maka pendidikan yang optimal juga akan tercipta dengan sendirinya. 


\section{Metode Penelitian}

Penelitian ini termasuk jenis penelitian studi literature dengan mencari referensi teori yang relefan dengan kasusu atau permasalahan yang ditemukan. Referensi teori yang diperoleh dengan jalan penelitian studi literature dijadikan sebagai fondasi desar dan alat utama dalam melakukan penelitian. Studi literaur adalah cara yang dipakai untuk menghimpun data-data atau sumber-sumber yang berhubungan dengan topic yang diangkat dalam suatu penelitian. Studi literature bisa didapat dari berbagai sumber.

Artikel ilmiah ini disususun dengan langkah langkah yang sistematis sehingga dapat memudahkan saya dalam melakukan penelitian. Pada artikel kali ini saya menggunakan metode study literatur dengan cara mengumpulkan literature berupa bahan bahan mateeri yang bersumber dari buku buku matakuliah administrasi dan supervise pendidikan yang ada di perpustakaan dan jurnal dan sumber lainnya terkait dengan administrasi layanan khusus di lingkungan Sekolah secara umum.

\section{KAJIAN TEORI DAN PEMBAHASAN}

\section{A. Pengertian Administrasi Pendidikan}

Administrasi layanan khusus di suatu sekolah merupakan bagian penting dalam Manajemen Berbasis Sekolah (MBS) yang efektif dan efisien.sekoalh merupakan suatu sarana yang bertujuan untuk mencerdaskan kehidupan suatu bangsa termasuk Negara Indonesia. Hal ini sesuai dengan UU No. 19 Tahun 2005 tentang Standar Nasional Pendidikan Bab II Pasal 4 yang memuat tentang adanya tujuan pendidikan nasional. Untuk memenuhi tugas dan tanggungjawab tersebut maka sekolah memerlukan suatu manajemen layanan khusus yang dapat mengatur segala kebutuhan peserta didiknya sehingga tujuan pendidikan tersebut dapat tercapai.

Administrasi layanan khusus di sekolah pada dasarnya ditetapkan dan diorganisasikan untuk mempermudah atau memperlancar pembelajaran, serta dapat memenuhi kebutuhan khusus siswa di sekolah. Pelayanan khusus diselenggarakan di sekolah dengan maksud untuk memperlancar pelaksanaan pengajaran dalam rangka pencapaian tujuan pendidikan di sekolah. Pendidikan di sekolah antara lain juga berusaha agar peserta didik senanatiasa berada dalam keadaan baik. Baik disini menyangkut aspek jasmani maupun rohaninya. Dari uraian tersebut dapat disimpulkan bahwa manajemen layanan khusus adalah suatu proses kegiatan memberikan pelayanan kebutuhan kepada peserta didik untuk menunjang kegiatan pembelajaran agar tujuan pendidikan bisa tercapai secara efektif dan efisien.

Administrasi layanan khusus adalah memberi layanan secara khusus atau suatu usaha yang tidak secara langsung berkenaan dengan proses belajar mengajar di kelas. Tetapi secara khusus diberikan oleh sekolah kepada para siswamnya agar mereka lebih optimal dalam melaksanakan proses belajar.

Manajemen layanan khusus di sekolah pada dasarnya ditetapkan dan di organisasikan untuk mempermudah atau memperlancar pembelajaran, serta dapat memenuhi kebutuhan khusus siswa di sekolah. Pelayanan khusus diselenggarakan di sekolah dengan maksud untuk memperlancar pelaksanaan pengajaran dalam rangka pencapaian tujuan pendidikan di sekolah. Pendidikan di sekolah antara lain juga berusaha agar peserta didik senanatiasa berada dalam keadaan baik. Baik disini menyangkut aspek jasmani maupun rohaninya. Dari uraian tersebut dapat disimpulkan bahwa manajemen layanan khusus adalah suatu proses kegiatan memberikan pelayanan kebutuhan kepada peserta didik untuk menunjang kegiatan pembelajaran agar tujuan pendidikan bisa tercapai secara efektif dan efisien.

\section{B. Jenis-Jenis Layanan Khusus dan Pengelolaannya.}

Pelayanan khusus yang diberikan sekolah kepada peserta didik, antar sekolah satu dengan sekolah lainnya pada umumnya sama, tetapi proses pengelolan dan pemanfaatannya yang berbeda. Beberapa bentuk layanan khusus yang ada di sekolah antara lain yaitu:

\section{Pustaka}

Perpustakaan merupakan salah satu unit yang memberikan layanan kepada peserta didik, dengan maksud membantu dan menunjang proses pembelajaran di sekolah, melayani informasi-informasi yang dibutuhkan serta memberi layanan rekreatif melalui koleksi bahan pustaka.

Menurut (Supriyadi,1983) dalam buku Manajemen Peserta Didik oleh Ali Imron mendefinisikan perpustakaan sekolah sebagai perpustakaan yang diselenggarakan di sekolah guna menunjang program belajar mengajar di lembaga pendidikan formal seperti sekolah, baik sekolah tingkat dasar maupun menengah, baik sekolah umum maupun kejuruan. (Yolanda \& Afriansyah, 2015).

Ada beberapa jenis perpustakaan sekolah, yang pada dasarnya disesuaikan dengan jenjang atau tingkat sekolah yang bersangkutan. Jenis perpustakaan sekolah tersebut adalah perpustakaan taman kanak-kanak, perpustakaan sekolah dasar, perpustakaan sekolah lanjutan tingkat pertama dan perpustakaan sekolah lanjutan tingkat atas. Semua jenis perpustakaan sekolah yang disebutkan diatas dikelola berdasarkan tujuan khusus masing-masing jenis dan jenjang sekolah.

Fungsi perpustakaan sekolah adalah:

1) Fungsi pendidikan

2) Fungsi informasi

3) Fungsi rekreasi

4) Fungsi penelitian

5) Fungsi penyaluran hobi

6) Fungsi penanaman rasa tanggung jawab

\section{Labor}

Labolatorium secara sederhana dapat diuraikan sebagai suatu tempat dimana dosen, mahasiswa, guru, siswa, dan orang lain melaksanakan kegiatan kerja ilmiah seperti pratikum, observasi, penelitian, demokrasi dan pembuatan model-model dalam rangka kegiatan belajar mengajar. 
Labolatorium dapat dibedakan atas berapa jenis. Jenis-jenis laboratorium tersebut biasanya disesuaikan dengan bidang studi atau kelompok bidang studi tertentu. Jenis laboratotium tersebut antra lain:

Menurut bidang studi misalnya: labolatorium kimia, fisika, pmp dan sebagainya

Menurut kelompok bidang studi misalnya : laboratorim IPS, IPA

Untuk bidang ilmu teknik labor dapat diartikan sebagai workshop/ bengkel kerja.

\section{UKS}

Usaha Kesehatan Sekolah merupakan salah satu wahana untuk meningkatkan kemampuan hidup sehat yang pada gilirannya menghasilkan derajat kesehatan peserta didik yang optimal. Usaha kesehatan sekolah tersebut bukan saja menjadi tanggung jawab pemerintah akan tetapi tanggung jawab peserta didik dan masyarakat dimana sekolah itu berada.

Layanan kesehatan peserta didik adalah suatu layanan kesehatan masyarakat yang dijalankan di sekolah dan menjadikan peserta didik sebagai sasaran utama, dan personalia sekolah yang lainnya sebagai sasaran tambahan (Imron, 1995:154)

Tujuan khusus usaha kesehatan sekolah adalah agar siswa:

1) Memiliki pengetahuan, sikap dan keterampilan untuk melaksanakan prinsip hidup sehat serta berpartisipasi aktif didalam usaha peningkatan kesehatan disekolah, dirumah tangga maupun dilingkungan masyarakat.

2) Sehat dalam arti fisik mental maupun social

3) Memiliki daya khayat dan daya tangkal terhadap pengaruh buruk, penyalahgunaan narkotika, obat dan bahan berbahaya, alcohol, rook, dan sebagainya.

\section{Kafetaria Sekolah}

Pertimbangan awal pendirian kafetaria/warung/kantin sekolah adalah bukan karena unsur bisnis semata, tanpa memperhitungkan aspek lain yang lebih penting. Keberadaan kafetaria/warung/kantin sekolah diharapkan mampu menyokong kelancaran proses belajar mengajar dari sisi keperluan akan makanan bagi siswa.

Kafetaria/warung/kantin sekolah secara tidak langsung mempunyai kaitan dengan proses belajar-mengajar di sekolah. Adakalanya proses belahar-mengajar tidak dapat berjalan sebagaimana mestinya karena siswa lapar dan haus.

\section{Sarana Ibadah}

Bagi para peserta didik khususnya jenjang pendidikan menengah dan pendidikan tinggi, terutama bagi mereka yang jauh dari orang tuanya diperlukan diperlukan asrama. Selain manfaat untuk peserta didik, asrama mempunyai manfaat bagi para pendidik dan petugas asrama tersebut.
Layanan asrama sekolah sangat bermanfaat bagi peserta didik, diantaranya:

1) Tugas sekolah dapat dikerjakan dengan cepat dan sebaik-baiknya terutama jika berbentuk tugas kelompok.

2) Sikap dan tingkah laku peserta didik dapat diawasi oleh petugas asrama dan para pendidik

3) Jika diantara peserta didik mengalami kesulitan (misalnya: kiriman orangtua terlambat), dapat saling membantu

6. Koperasi

Koperasi berasal dari dua kata, yaitu co dan operation, yang berarti kerja sama untuk mencapi tujuan. Koperasi adalah "suatu perkumpulan yang beranggotakan beberapa orang atau badan-badan, dengan bekerja sama dengan menggunakan asas kekeluargaan dalam menjalankan usaha, serta untuk mempertinggi kesejahteraan jasmaniah para anggotanya".

\section{Transportasi}

Sarana transportasi bagi peserta didik merupakan sarana penunjang untuk kelancaran proses belajar mengajar. Peserta didik akan merasa aman dan dapat masuk atau pulang dengan waktu yang tepat. Transportasi yang diperlukan terutama bagi peserta didik ditingkat prasekolah dan sekolah dasar. Penyelenggara transportasi sebaiknya dilaksanakan oleh sekolah yang bersangkutan atau pihak swasta.

\section{Sarana Ibadah}

Di setiap sekolah, layanan rumah peribadatan sangat diperlukan. Layanan rumah peribadatan merupakan sebuah layanan yang diberikan sekolah dengan maksud agar layanan tersebut bisa digunakan untuk beribadah maupun melaksanakan kegiatan keagamaan lainnya, serta bisa membentuk kerohanian bagi peserta didik khususnya pada pihak sekolah lain pada umumnya. Agar bisa menjadi manusia yang baik dan beriman.

Adanya sebuah layanan rumah peribadatan di sekolah sangat menunjang proses pembelajaran mengingat bahwa pembelajaran bisa dilakukan dimana saja temasuk salah satunya adalah di rumah peribadatan. Adapun layanan rumah peribadatan yang biasanya ada di sekolah adlah masjid dan gereja.

\section{Peran Guru Dalam Administrasi Layanan Khusus}

Administrasi layanan khusus ini tidak secara langsung berkenaan dengan proses belajar mengajar di kelas, tetapi khusus diberikan oleh sekolah kepada siswanya agar mereka lebih optimal dalam melaksanakan proses belajar. Peran guru dalam administrasi layanan khusus antara lain: a. Keterlibatan guru dalam administrasi perpustakaan misalnya memperkenalkan buku-buku kepada siswa.

b. Mengetahui jenis dan menguasai kriteria umum yang menentukan baik buruknya suatu koleksi buku-buku perpustakaan. 
c. Mempromosikan perpustakaan baik pemakaian maupun untuk pembinaannya.

Ada berbagai jenis layanan khusus, empat diantaranya adalah perpustakaan sekolah, koperasi sekolah, usaha kesehatan sekolah dan kafetaria sekolah.

1) Perpustakaan Sekolah

Sekolah dapat menunjuk wakilnya atau salah seorang guru yang dianggapnya mampu bertanggung jawab dalam administrasinya. Apabila kepala sekolah memberikan tugas administrasi perpustakaan itu kepada guru, maka guru tersebut hendaknya diberi keringan jumlah jam mengajarnya sehingga ia dapat memikirkan lebih baik tentang pengembangan perpustakaannya.

Sebelum bahan pustaka yang ada di perpustakaan dapat sampai kepada pengunjung, koleksi/bahan pustaka itu harus diolah terlebih dahulu. Pengolahan itu melalui tahap-tahap (1) inventarisasi, (2) katalogisasi, (3) klasifikasi, (4) pemberian nomor buku buku, dan (5) penyusunan buku di rak.

Keterlibatan Guru dalam Administrasi Perpustakaan. Tidak semua guru sekolah menengah harus terlibat langsung dalam administrasi perpustakaan sekolah. Nasution (1981) mengemukakan keterlibatan guru dalam perpustakaan itu antara lain:

a) Memperkenalkan buku-buku kepada para siswa dan guru. b) Memilih buku-buku dan bahan pustaka lainnya yang akan digunakan untuk menambah koleksi perpustakaan sekolah.

c) Mempromosikan perpustakaan, bauk untuk pemakaian, maupun untuk pembinaannya.

d) Mengetahui jenis dan menguasai kriteria umum yang menentukan baik-buruknya suatu koleksi.

e) Mengusahakan agar siswa aktif membantu perkembangan perpustakaan.

\section{2) Koperasi Sekolah}

Koperasi berasal dari perkataan co dan operation, yang mengandung arti kerja sama untuk mencapi tujuan. Oleh sebab itu definisi koperasi dapat diberikan sebagai berikut:

Koperasi adalah "suatu perkumpulan yang beranggotakan orang-orang atau badan-badan, yang memberikan masuk dan keluar sebagai anggota; dengan bekerja sama secara kekeluargaan menjalankan usaha, utuk mempertinggi kesejahteraan jasmaniah para anggotanya". Tersebut mengandung unsur-unsur bahwa:

a) Perkumpulan koperasi bukan merupakan perkumpulan modal (bukan akumulasi modal), akan tetapi persekutuan sosial.

b) Sukarela untuk menjadi anggota, netral terhadap aliran dan agama.

c) Tujuannya mempertinggi kesejahteraan jasmaniah anggota-anggota dengan kerja sama secara kekeluargaan.

Kerja sama dalam masyarakat modern telah nampak wujudnya dalam suatu jaringan sistem yang lebih kompleks. Bentukbentuk ikatan perekutuan hidup telah berkembang dan menjadi lebih beragam. Kini kerja sama di samping memenuhi kebutuhan menjaga kelangsungan hidup dan rasa aman, juga untuk memperoleh kasih sayang dan persahabatan seperti dalam keluarga dan paguyuban, juga telah digunakan untuk mencapai tujuan-tujuan tertentu yang diinginkan, seperti nampak pada bentuk-bentuk organisasi yang resmi.

\section{3) Kafetaria Sekolah}

Pertimbangan awal pendirian kafetaria/warung/kantin sekolah adalah bukan karena unsur bisnis semata, tanpa memperhitungkan aspek lain yang lebih penting. Keberadaan kafetaria/warung/kantin sekolah diharapkan mampu menyokong kelancaran proses belajar mengajar dari sisi keperluan akan makanan bagi siswa.

Kafetaria/warung/kantin sekolah secara tidak langsung mempunyai kaitan dengan proses belajar-mengajar di sekolah. Adakalanya proses belahar-mengajar tidak dapat berjalan sebagaimana mestinya karena siswa lapar dan haus.

Kafetaria/warung/kantin sekolah tidak harus diadministrasikan oleh sekolah, tetapi dapat diadministrasikan oleh pribadi di luar sekolah atau oleh darma wanita sekolah. Namun kafetaria/warung/kantin sekolah ini tidak boleh terlepas dari perhatian kepala sekolah. Kepala sekolah harus memikirkan atau mengupayakan kehadiran kafetaria/warung/kantin sekolah itu mempunyai sumbangan positif dalam proses belajar-mengajar anak di sekolah.

Beberapa hal yang harus diperhatikan dalam administrasi kafetaria itu adalah:

a) Administrasi kafetaria/warung/kantin sekolah harus menjaga kesehatan (higienitas) masakan-masakan yang dijajakan kepada siswa.

b) Kebersihan tempat juga harus menjadi pertimbangan utama, karena kebersihan diharapkan dapat menjauhkan penyebaran hama penyakit.

c) Makanan-makanan yang disediakan hendaknya makanan yang bergizi tinggi, dan bilamana perlu dapat menambahkan vitamin-vitamin yang diperlukan siswa pada umumnya.

d) Harga makanan-makanan hendaknya dapat dijangkau atau sesuai dengan kondisi ekonomi siswa.

e) Usahakan agar kafetaria/warung/kantin sekolah tidak memberikan kesempatan kepada siswa untuk berlamalama atau nongkrong. Kondisi yang demikian akan menyokong munculnya perilaku-perilau negatif.

\section{4) Unit Kesehatan Sekolah (UKS)}

Usaha Kesehatan Sekolah adalah suatu layanan yang bertujuan untuk membantu meningkatkan kualitas pendidikan di sekolah dengan cara memberikan pelayanan kesehatan di sekolah. Biasanya di UKS disediakan sebuah fasilitas untuk istirahat seperti tempat tidur dan obat-obatan. Hal itu sangat dibutuhkan oleh murid atau guru maupun karyawan jika terjadi sesuatu hal. Organisasi UKS diatur sesuai dengan keadaan sekolah. Kepala sekolah bisa menunjuk bawahannya untuk mengatur keorganisasian dari pada UKS tersebut. 


\section{KESIMPULAN}

Secara umum pengertian administrasi adalah segenap proses penataan kerjasama dari sekelompok orang dengan menggunakan fasilitas dan perlengkapan yang ada untuk memperlancar dan mengefisienkan pencapaian tujuan dari suatu organisasi. Layanan khusus diberikan oleh sekolah kepada para siswamnya agar mereka lebih optimal dalam melaksanakan proses belajar. Administrasi layanan khusus disekolah pada dasarnya ditetapkan dan di organisasikan untuk mempermudah atau memperlancar pembelajaran, serta dapat memenuhi kebutuhan khusus siswa di sekolah. Layanan khusus diberikan oleh sekolah kepada para siswanya agar mereka lebih optimal dalam melaksanakan proses belajar. Administrasi layanan khusus di sekolah pada dasarnya ditetapkan dan di organisasikan untukmempermudah atau memperlancar pembelajaran, serta dapat memenuhi kebutuhan khusus siswa di sekolah.

\section{Daftar Pustaka}

Afriansyah, H. (2019). Administrasi Layanan khusus. Padang: osf.io/sc6ap. Diambil dari https://osf.io/eqtfb/

Ali, Imron.(1995). Perpustakaan Sekolah.Hal 154.

Supriyadi. (1983). Manajemen Peserta Didik.

Kusmintardjo. (1992). Layanan Khusus di sekolah. 